\title{
Article
}

\section{Import Risks of Agricultural Products in Foreign Trade}

\author{
Lina Baranauskaitè ${ }^{1, *}$ and Daiva Jurevičiene ${ }^{2}$ (D) \\ 1 Institute of Economics and Rural Development, Lithuanian Centre for Social Sciences, \\ LT-03220 Vilnius, Lithuania \\ 2 Department of Economics Engineering, Vilnius Gediminas Technical University, LT-10223 Vilnius, Lithuania; \\ daiva.jureviciene@vilniustech.lt \\ * Correspondence: lina.baranauskaite@laei.lt; Tel.: +370-5-261-14-81
}

Citation: Baranauskaitè, Lina, and Daiva Jurevičienè. 2021. Import Risks of Agricultural Products in Foreign Trade. Economies 9: 102. https:// doi.org/10.3390/economies9030102

Academic Editors: Michał Roman and Monika Roman

Received: 29 April 2021

Accepted: 22 June 2021

Published: 5 July 2021

Publisher's Note: MDPI stays neutral with regard to jurisdictional claims in published maps and institutional affiliations.

Copyright: (c) 2021 by the authors. Licensee MDPI, Basel, Switzerland. This article is an open access article distributed under the terms and conditions of the Creative Commons Attribution (CC BY) license (https:/ / creativecommons.org/licenses/by/ $4.0 /)$.
Abstract: This paper aims to identify the main risk groups according to their significance on imports of agricultural products. After analysis of the scientific literature, eight groups of risks associated with agricultural products import were determined: supply risks, demand risks, production risks, management plus operational risks, logistical plus infrastructural risks, political risks, policy plus regulatory risks and financial risks. In order to assess the importance of all import risk groups, three Multicriteria decision support methods (MCDM)-SAW, TOPSIS and Geometric meansfor expert evaluation are used. The article introduces a new import risks assessment framework CIRA (Country's Imports Risk Assessment) contributing to the systematic approach of a country's international trade risks management. The results order risk groups according to their importance in the following order: production (the most crucial risk group), logistical plus infrastructural, financial, management plus operational, political, supply, policy plus regulatory and demand risks.

Keywords: import risks; agricultural products; agro-trade; food import; SAW; TOPSIS; geometric means

\section{Introduction}

In 1919, J. M. Keynes already expressed the wish that, "the inhabitant of London could order by telephone, sipping his morning tea in bed, the various products of the whole earth... and reasonably expect their early delivery upon his doorstep" (Keynes and Volcker 1920, p. 50). What was once a courageous wish has now become reality. During Industry 4.0, especially due to the COVID-19 pandemic, many ordinary customers are accustomed to modern trade tools such as various e-commerce channels for ordering goods from different parts of the world, with delivery to their destinations (Mehrolia et al. 2020). Global supply chains and their potential are no longer surprising. The main point of interests become customer wishes, prices and terms of delivery. Shrinking trade restrictions between countries, which mainly consists of free trade agreements, technological opportunities and countries aiming to boost trade, have led to transactions with an increasing number of international trade partners and results in increasing chances and increasing business risk.

On the other hand, trade growth has affected the risk increase in the food sector. For example, after the horsemeat scandal in 2013, the importance of food safety has increased in Europe (Rieger et al. 2016). Cases of food scandals encouraged more research, which revealed more facts that are significant. The NAO (2013) reported, "Recent analysis of the components of a pizza, carried out for the Food Safety Authority of Ireland, found that pizza was made from 35 different ingredients that passed through 60 countries, on five different continents". Since 2013, globalisation is still growing. Countries are increasingly interlinked and processes are becoming more and more challenging to maintain. International trade regimes (e.g., import bans) and technical possibilities (e.g., border controls) cannot fully guarantee import security, thereby increasing the risk of unsafe food imports (Skuland 2020).

However, the risk of unsafe food imports is not the only one related to imports. Studies of the World Economic World Economic Forum (2019) revealed the world's most 
considerable potential risks (e.g., climate change risk) and identified the most significant risks affecting the whole world. The majority will affect the agro sector. The OECD (2020) notes that agricultural policymakers mainly focus on primary agrarian production problems. A food systems approach emphasises the possible effects of agricultural policies on nutritional and environmental outcomes. The results achieved by the world food system from the 1960s to the present show impressive achievements: the world's population has more than doubled and world food production has tripled. Thus, more food per person is provided at a lower price and achieved through increased productivity. It would be impossible to balance the population's nutritional needs with environmental well-being. Among other things, food systems provide a livelihood for those working in farms worldwide and the agro sector's food supply. Food systems depend on natural resources and must simultaneously contribute to environmental sustainability and people's livelihoods. The "triple challenge" is marked as a strike balance between food security and nutrition, ensuring people's livelihoods and ecological sustainability in pursuit of Sustainable Development Goals. There is no doubt that food systems face a daunting triple task that needs to be addressed urgently by seeking synergies between trade-offs and policy coherence challenges (OECD 2020).

Nevertheless, international trade is essential for all countries, especially for small ones since their economic development is based on international trade. It is noticeable that most policy measures promote exports (EC 2015), while imports are not encouraged (Moreno and García-Álvarez 2018; Van den Berg et al. 2017; Wymenga et al. 2013; Kulikov and Minakov 2018). Van den Berg et al. (2017) studies look at the link between imports and a firms' productivity. Although scientists note that the relations between the company's import and export performance are not fully explored, productivity is an intermediate factor in importexport relations. Wagner (2013) studies show that importing firms are more productive than non-importing firms are. The link between importing and productivity is manifold (Van den Berg et al. 2017).

While international trade is widely studied around the world, it does not address the risks related to it (Gervais 2018). The response to threats remains quite essential and responsible, ensuring stability and trade of each country. It is evident that import risks were previously analysed separately (Huang et al. 2017; Caccavale and Giuffrida 2020; Hyuha et al. 2017; Shmatko et al. 2020; Caccavale and Giuffrida 2020) or incorporated into global supply chains (Zhao et al. 2020; Behzadi et al. 2018; Laborde et al. 2020). The gap is noticeable in analysing import risks for a single country. Import risks can harm a country's trade and their management can improve a country's trade performance.

The purpose of this article is to identify the main risk groups for imports that need to be examined in the context of trade in agricultural products in the country and to adapt them according to their importance for the management of international trade. Research focuses on the macro-level risks without going into micro risks incurred vis-à-vis enterprises. Analyses of the scientific literature and Multicriteria decision methods are used. The risk groups set out in this article could help to manage a country's argo trade. Current work introduces a new imports risk assessment framework, CIRA, contributing to the systematic approach to a country's international trade risks management. The case of Lithuania is used.

\section{Literature Analysis}

Import risks are analysed by researchers from a variety of perspectives and for different purposes. Some articles identify risks and seek solutions to mitigate them (e.g., Zobov et al. 2017, etc.). Other articles identify, assess and provide recommendations to reduce risks (e.g., Welburn et al. 2016, etc.). Since the agricultural sector provides everyday products that affect the quality of life, it is the cornerstone of each country. Despite this, the farm sector is analysed as a risky and sensitive sector (Novickyte 2019). The risk of production is identified as one of the highest (Hardaker et al. 2015). It is noticeable that low cost and price competition is decreasing worldwide and it remains dominant in those sectors where the 
main factors involved in production are natural resources and low-skilled labour, which is relevant to the agricultural and food sector (Drozdz 2018).

The literature analysis reveals five types of import-related risks: (1) food security, (2) food quality (food safety risks), (3) risks for natural resources (risk of uneven distribution of natural resources due to the trade), (4) risks for the labour market and (5) risk of stable supply.

Many scientists devoted their research to import security risks (Huang et al. 2017; Caccavale and Giuffrida 2020; Hyuha et al. 2017, etc.). Import security risks are risks related to importing a sufficient quantity of food at affordable prices and in the required period. Despite all the risks, imports are organised for three purposes: import to produce, to re-export and import to consume. It is important to manage all these flows of goods to achieve their trade objectives. Feng et al. (2016) confirmed complementarity between imports and exports. They noticed that product improvement through technology and quality development depends on imported raw materials. It has been observed that all companies that have expanded their imports of intermediate raw materials have grown their export volumes, but the distribution of benefits remains uneven. The distribution depends on the source of import, industry intensity and the conditions of the company's ownership.

The most significant impact was observed when imports were made by private sector producers rather than by non-traders. Comparing import sources showed that intermediate costs from higher-income countries were more beneficial and facilitated exports to more demanding and profitable G7 markets. Van den Berg et al. (2018) examined the link between imports and firms' productivity, where productivity is an intermediate factor in importexport relations. Scientists note that the connection between the company's import and export performance has not yet been fully explored (Van den Berg et al. 2018). Wagner (2012) research shows that importing firms are more productive than non-importing because importers themselves enter international and global supply markets and buy higher quality intermediate products at lower costs, which contributes to the competitiveness of their products. Moreover, participation in the international network provides opportunities to purchase more innovative technological products and to obtain foreign suppliers' tactics (Van den Berg and Van Marrewijk 2017).

Some authors analyse factors of one risk type, e.g., demand risks (Hyuha et al. 2017) or logistics (Shmatko et al. 2020). Others analyse risk factors along the entire supply chain (Zhao et al. 2020; Behzadi et al. 2018) or key risks to global food security (Laborde et al. 2020). Some studies cover all or several food groups and some studies examine the risks of only one food product (e.g., rice, cereals, etc.). The country's food security is a critical factor for governments that do not produce enough available food in their own countries. The reasons may range from insufficient natural resources for agricultural production: mountain areas, soil, water pollution and growing population (such as China, Korea, Japan, etc.). Analyses by Hyuha et al. (2017) showed that the determinants of import demand in the context of food security and concluded that one can control import demand by managing the following main factors: population growth, domestic production, prices in the country and countries domestic consumption. The research shows that the government could be self-sufficient and save foreign exchange costs if it controls high population growth and increases domestic production through high-yielding technologies by supporting farmers to increase domestic food production and by stabilising prices.

As international trade unites all countries and all countries are largely bound by the ideas of free trade and the work of international institutions such as the WTO, the prosperity of some countries depends on the possibilities provided by others. In many cases, the well-being of one country can be a threat to the well-being of other countries and this is particularly noticeable in the context of food security. Some countries lack food resources and others export those resources for financial gain. Many scientists analyse the dependence risk of food import (Huang et al. 2017; Caccavale and Giuffrida 2020; Hyuha et al. 2017; etc.). Often, the most significant threats are due to the capabilities and actions of 
large countries. According to Huang et al. (2017), China will manage its import security risks and will not be at risk of the growing demand for food in the world in the foreseeable future. Among other things, imports of feed and certain specific foods (say soybean, bread, dairy products and sugar) could provide an opportunity for many exporting countries to expand their production and export to the Chinese market. Caccavale and Giuffrida (2020) analysed food security indexes (e.g., the Global Hunger Index (GHI), the Global Food Security Index and the Ending Rural Hunger Index) and proposed a new composite food security index, rendering it possible to measure the country's food security. Yu et al. (2019) dealt with the "triple high phenomenon" in China's cereals sector, where a high level of domestic production at that time did not result in a decrease in imports even when the stocks were high. A group of scientists analysed import security risks by analysing import substitution possibilities (Zobov et al. 2017). They stated that one can achieve the goals of import substitution only through the modernisation of production and the introduction of innovative technologies in the food industry. Khanal et al. (2018), by analysing trends in import and domestic production demand, found that product selection priorities differ between countries. The local population in some countries prefer local products (e.g., milk and tomatoes) to imported products.

Food quality risks (food safety risks) due to the health effects of imported food are examined by many scientists (Welburn et al. 2016; Herrera-Herrera et al. 2019; Attrey 2017; Ruhm 2016; Smith et al. 2017; Pietrzyck et al. 2021, etc.). The researchers analyse the safety of imported food for health by taking into account many aspects: countries of origin, products groups, qualitative parameters and trend of irregularities. Each country seeks to protect the health of its population by controlling the quality of imported food. Importing and exporting countries often have different systems and procedures for food inspection and certification. Compliance with quality requirements is a significant goal for many countries wishing to export. Welburn et al. (2016) analysed US food import risk infringements detected under the Operational and Administrative System for Import Support (OASIS) of the Food and Drug Administration (US FDA). Risks differ by product type (e.g., among fish products, vegetables or dairy products groups), type of infringement, economic factors (GDP) of the country and by the country of origin. Herrera-Herrera et al. (2019) investigated the content of heavy metals in fish from Colombia. Smith et al. (2017) analysed infectious risks related to importing to the US. The Attrey (2017) study showed that food quality control measures during inspections are effective and create confidence in the safety and quality of food supply. However, according to the authors, quality requirements can sometimes be an obstacle to international trade in food products. Increasing focus on the introduction and implementation of trade-distorting rules and regulations is making trade more difficult. Focusing on tightening the rules opens the opportunity to bypass the purpose of trade. As recommended by the WTO, cooperation in exporting and importing countries is becoming a cornerstone to ensure smooth and secure trade. Existing control systems should be set up following the approved guidelines.

Further studies analysed food safety from another perspective. Otero et al. (2018), looking at obesity problems and stated that food choices are structurally conditioned by income inequality and food supply offer. According to this study, people eat what huge oligopolistic food producers offer together with distributors. Moreover, the neoliberal position of a state creates the conditions for the market situation. Researchers have proposed a neoliberal diet risk index to assess people's risk of wholesome food. The index expands the limitations of existing measures, which usually hides the inequalities within countries.

Resource use risk is understood as the risk of unequal distribution of natural resources due to international trade in agricultural products. This risk focuses on the sustainable use of limited natural resources (e.g., water and soil) to produce food products and the distribution of emissions due to trade between countries. It is recognised that agriculture is linked to the use of natural resources. Different countries have an uneven approach to natural resources. Moreover, the production of both basic foods and all other food products requires various resources. For example, some countries lack suitable soil, others 
lack water or lack fertiliser. In the course of trade, there is a risk that available economic resources will be over-exploited. The Zhu et al. (2019) study assesses the potential of China's water resources for agricultural production by the water stress index. They note that the processing industry can participate in the development of innovative technologies to address declining resources. Gemechu et al. (2016) analysed the risks of the supply and the sustainable supply of raw materials differentiated by countries according to import patterns. Bach et al. (2016, 2017) addressed pollution issues due to the global changes in industry and technical logic. A demand for abiotic resources has led to the increased pollution of natural resources, such as water and soil.

Only a few studies analysed the labour market import risk. Adda and Fawaz (2020) evaluated the impact of import competition on the labour market and the health of US workers and found that import shocks harm human employment, income and human health. They determined that imports had harmful effects on human physical and mental health, especially in areas where there is intense survivability competition. As a result, it has been observed that access to health care in those areas has declined, rendering the disease more severe. Then, more patients were hospitalised for their treatment. The impact of imported products on the market has led to an increase in the mortality of manufacturing workers. Lang et al. (2019), by examining the growth of imports from China, also found a negative impact in those areas on employment, income and health of the population.

Colantone and Stanig (2018) revealed the impact of globalisation on the results of the EU elections. The author examined the impact of Chinese imports on different regions and the results of their votes. According to the study, support for nationalist and isolationist parties for radical-right parties increased due to a stronger import shock. This reflects the results of the regional elections as revealed by the analysis of individual voting choices. Therefore, import risk can have a direct impact on the country's governance.

The increase in regional trade agreements (RTAs) reflects the growing need for such contracts in the last decades. The WTO's attempt to secure free trade agreements is limited (Hoekman 2019) and not all countries are well willed and equally treatable (e.g., usage of non-tariff barriers). Governments tend to benefit and gain specific advantages of trade using a variety of instruments. There are also different commercial reasons. It was found that, according to factors contributing to the increase in RTAs analysis, the usage of common languages and the influence of distances play an essential role. On the other side, geographical indication does not play a significant role in regional trade agreements (Jámbor et al. 2020). Moreover, it has been proven that countries trade with each other based on the size of their GDP, population, cultural affinity, institutional support and physical proximity (Jindřichovská 2020). The main reasons for trade often lie outside trade in agro products. Countries are promoting trade and seeking to maximise benefits, which does not always have a positive impact on the agro sector of the country.

Therefore, in order to improve risk management performance, there is a need to manage many supply chain risks effectively and efficiently. Many scientists (Zhao et al. 2020; Behzadi et al. 2018; Hyuha et al. 2017; Nyamah et al. 2017, etc.) analysed supply chain risks. Risks and uncertainty in supply chains are becoming increasingly relevant as food supply chains become more complex, especially in times of shocks such as pandemics. The interest in assessing vulnerabilities of supply chains, disruptions and disturbances increased. Some scientists analyse threats, crises and robustness effects. The analysis of supply chains includes many risks, such as output risk, market risks (covering both supply and demand risks), uninterrupted supply risk and substitutability of output as a factor in reducing output risk. For food security purpose, researchers analyse different risk factors and group them into different risk types. For example, Ho et al. (2015), by summarising literature of various supply chain risks, divide risk factors into macro-risks, micro-risks (demand, manufacturing and supply risks) and different types of flow (information, transportation and financial risks). Nyamah et al. (2017) and later Zhao et al. (2020), by analysing the entire supply chain risk factors, divide all factors into nine risk groups: demand-side risks, supply-side risks, biology and environmental risk, weather-related risks, management and 
operational risks, logistical and infrastructural risk, policy and regulatory risks, political risks and financial risks. The authors also assess the critical risk factors found throughout the supply chain, which include the primary material source to the end consumer regardless of how many countries are involved in the supply chain. The COVID-19 pandemic has led to the stronger management of supply chain risks and more risk studies on food supply chains (Laborde et al. 2020; Sharma et al. 2020; Aday and Aday 2020; Jablonski et al. 2021). The revealed period of the pandemic showed that not only food supply companies but also different industries are closely connected. Any disruption in one part of the supply chain breach affects disruptions throughout the global supply chain (Aday and Aday 2020). Technological development enabled the use of advanced strategies and technologies for supply chain risk management, such as machine learning and big data (Ivanov et al. 2019; Baryannis et al. 2019).

To summarize, all risk factors posed by imports were divided into eight risk groups according to their nature. The framework including CIRA's main risk groups and their primary factors are presented in Table 1.

Table 1. Groups of food import risk and their factors (created by authors, 2021).

\begin{tabular}{|c|c|c|}
\hline Group of Risk & Factors & Authors \\
\hline Supply risks & $\begin{array}{l}\text { Foreign supplier bankruptcy; capacity fluctuations/shortages on the } \\
\text { foreign supply market; yield uncertainty (related, e.g., with weather } \\
\text { conditions) of foreign suppliers; substitution availability; market price } \\
\text { volatility/fluctuations of foreign suppliers; lack of information sharing } \\
\text { between supply partners. }\end{array}$ & $\begin{array}{l}\text { (Zhao et al. 2020; Behzadi et al. 2018; } \\
\text { Nyamah et al. 2017; Welburn et al. 2016) }\end{array}$ \\
\hline Demand risks & $\begin{array}{l}\text { Volatility of customer demand; market price volatility / fluctuations; } \\
\text { local suppliers yield uncertainty (e.g., related with weather conditions); } \\
\text { insufficient information from customers; supply and demand } \\
\text { imbalance; substitution availability; changes in food safety } \\
\text { requirements; changes in labour disputes (threat to local labour market); } \\
\text { change in customer attitudes. }\end{array}$ & $\begin{array}{l}\text { (Nyamah et al. 2017; Otero et al. 2018; } \\
\text { Zhao et al. 2020; Welburn et al. 2016; } \\
\text { Behzadi et al. 2018; } \\
\text { Adda and Fawaz 2020;) }\end{array}$ \\
\hline Production risks & $\begin{array}{l}\text { Risks from pests, diseases and additives; contamination related to poor } \\
\text { sanitation and illnesses; perishability of the product; contamination } \\
\text { affecting food safety; substitution availability; resource dependency; } \\
\text { rapid technological development; contamination and degradation of } \\
\text { production and processing processes. }\end{array}$ & $\begin{array}{c}\text { (Zhao et al. 2020; Nyamah et al. 2017; } \\
\text { Welburn et al. 2016) }\end{array}$ \\
\hline $\begin{array}{l}\text { Management and } \\
\text { operational risks }\end{array}$ & $\begin{array}{l}\text { poor management (skill shortage); lack of investment in promoting } \\
\text { agro-food products; risks associated with contract fulfilment; poor asset } \\
\text { allocation management decisions; usage of expired products; poor } \\
\text { quality control; poor decision making in the use of inputs; equipment } \\
\text { breakdowns; inability to adapt to changes in cash and labour flows; } \\
\text { forecast and planning errors; tax evasion. }\end{array}$ & (Zhao et al. 2020; Nyamah et al. 2017) \\
\hline $\begin{array}{l}\text { Logistical and } \\
\text { infrastructural risks }\end{array}$ & $\begin{array}{l}\text { Poor supply infrastructure; lack of information sharing among partners; } \\
\text { high energy costs; volatility in fuel price; distribution system; poor } \\
\text { agricultural infrastructure; rapid technological development; poor } \\
\text { infrastructure and services; unreliable transport; undependable } \\
\text { transport; conflicts and labor disputes affecting transport; changes in } \\
\text { transportation; lack of infrastructure and service units; poor } \\
\text { performance of logistics service providers; lack of effective system } \\
\text { integration. }\end{array}$ & $\begin{array}{l}\text { (Nyamah et al. 2017; Shmatko et al. 2020; } \\
\text { Otero et al. 2018; Zhao et al. 2020) }\end{array}$ \\
\hline Political risks & $\begin{array}{l}\text { Political instability, war, civil unrest or other socio-political crises; } \\
\text { interruption of trade due to disputes with other countries; } \\
\text { nationalisation/confiscation of assets, especially belonging to foreign } \\
\text { investors; changes in the political environment due to introduction of } \\
\text { new laws or stipulations. }\end{array}$ & $\begin{array}{c}\text { (Nyamah et al. 2017; Spink et al. 2019; } \\
\text { Zhao et al. 2020) }\end{array}$ \\
\hline $\begin{array}{l}\text { Policy and regulatory } \\
\text { risks }\end{array}$ & $\begin{array}{l}\text { Distribution system stricter food quality and safety standards; animal } \\
\text { welfare legislation negatively affecting the competitiveness; trade } \\
\text { competitiveness legislation; potential restrictions on waste disposal; } \\
\text { weak institutional capacity to implement regulatory mandates. }\end{array}$ & $\begin{array}{l}\text { (Nyamah et al. 2017; Otero et al. 2018; } \\
\text { Welburn et al. 2016; Zhao et al. 2020; } \\
\text { Attrey 2017) }\end{array}$ \\
\hline Financial risks & $\begin{array}{l}\text { Delay in payment; possible non-payment; uncertain trade, market, land } \\
\text { and tax policies; inadequate financial support; change in exchange rate; } \\
\text { insufficient credit. }\end{array}$ & $\begin{array}{c}\text { (Zhao et al. 2020; Bachev 2017; } \\
\text { Nyamah et al. 2017) }\end{array}$ \\
\hline
\end{tabular}




\section{Methodology}

The framework CIRA with eight risk groups was developed and includes the following: supply risks, demand risks, production risks, management and operational risks, logistical and infrastructural risks, political risks, policy and regulatory risks and financial risks. An expert evaluation method was employed to assess chosen groups of risks according to their importance. It covers the following four steps: (1) development of a questionnaire; (2) selection of experts; (3) fulfilment of the survey; (4) interpretations of the survey results. Figure 1 presents the process of the research.

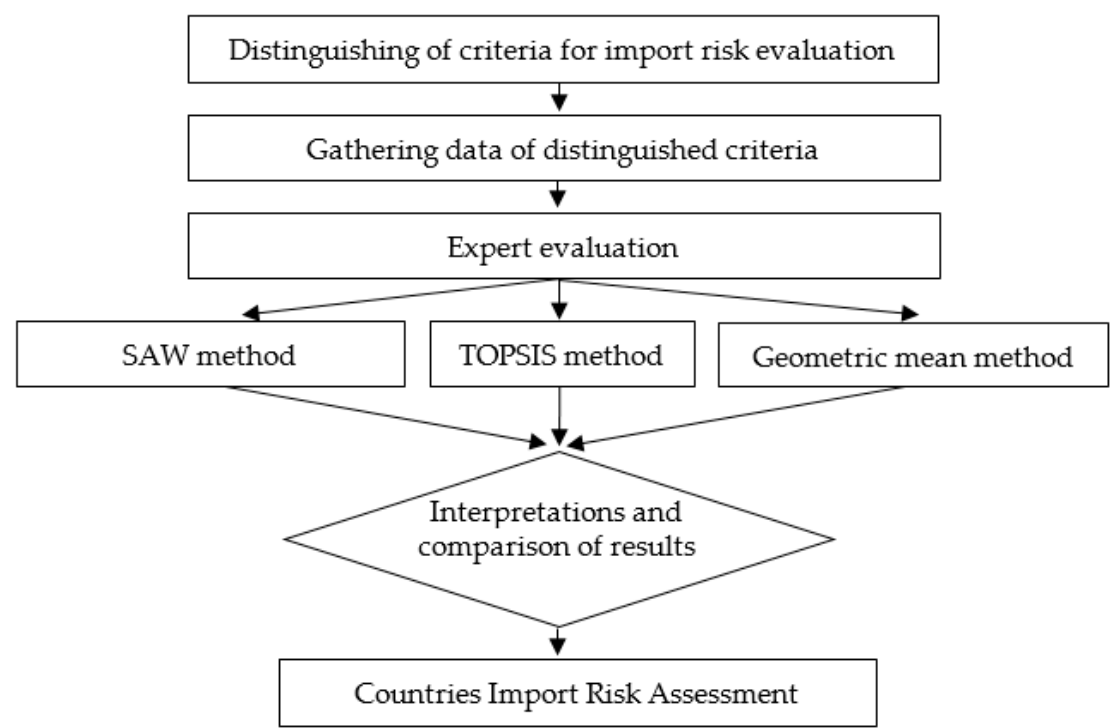

Figure 1. The process of the research.

The case of Lithuania is used for the research because of its geographical location and size. Furthermore, Lithuania is a small EU country for which trade occurs under all existing inter-lateral agreements with EU countries and other countries. Therefore, it faces all the risks inherent in a small open economy.

According to Libby and Blashfield (1978), seven experts (optimal number) participated in the survey. Table 2 represents qualitative information about the experts. The case of one country (Lithuania) is analysed. Most of the experts were from Lithuania. However, the international experts permitted us to observe the situation from a broader perspective and to have an impartial opinion. Experts filled in the questionnaire for each risk group. A three-level Likert scale was used (low risk, middle risk and high risk).

Table 2. Qualitative information about experts.

\begin{tabular}{cccc}
\hline Expert No. & Country & $\begin{array}{c}\text { Experience in } \\
\text { International Trade }\end{array}$ & Workplace (Leader Position) \\
\hline$E_{1}$ & Japan & More than 10 years & Government sector \\
\hline$E_{2}$ & Netherlands & More than 10 years & Government sector \\
\hline$E_{3}$ & China & More than 7 years & Government sector \\
\hline$E_{4}$ & Lithuania & More than 10 years & International Trade Association \\
\hline$E_{5}$ & Lithuania & More than 20 years & Scientific Institution \\
\hline$E_{6}$ & Lithuania & More than 20 years & Government sector \\
\hline$E_{7}$ & Lithuania & More than 15 years & Scientific Institution \\
\hline
\end{tabular}

Three Multicriteria decision support methods were used to assess the analysed risk groups and to obtain the most reliable research results: Simple Additive Weighting (SAW), 
Technique for Order Preference by Similarity to an Ideal Solution (TOPSIS) and Geometric mean.

SAW method is the most well known and most widely used. It was investigated by MacCrimmon (1968) and is treated as one of the most used multi-criteria decisionmaking methods. This method integrates the values of variables and weights into a single magnitude (Kraujaliene 2019). The application of the SAW method involves three steps: (1) ratios calculation to perform the normalization; (2) calculation of weighted sums of the normalised values; (3) prioritization of risk groups according to the calculated values. All Multicriteria decision methods have their advantages and disadvantages. The SAW method's disadvantage is that all criteria ought to be maximising. In addition, the SAW method requires all the criteria values $r_{i j}$ to be positive. In our case, all the criteria have positive values and so we did not need to convert them. After receiving the data of expert assessments, the calculation of maximising ratios to perform the normalization was conducted according to the following equation (Ginevičius and Podvezko 2008).

$$
\bar{r}_{i j}=\frac{r_{i j}}{\max _{j} r_{i j}}
$$

The normalization for risk indicators was calculated according to the following equation (Ginevičius and Podvezko 2008).

$$
\bar{r}_{i j}=\frac{r_{i j}}{\sum_{j=1}^{n} r_{i j}}
$$

After the normalization procedure, weighted sums of normalised risk values were calculated according to Equation (3) (Ginevičius and Podvezko 2008):

$$
S_{j}=\sum_{i=1}^{m} w_{i} \bar{r}_{i j}
$$

where:

$w_{i}$-the weight of the $i$ th criterion;

$\bar{r}_{i j}$-normalised value from formula (1) and; $m$-number of criteria used for risk evaluation.

Risk groups are ranked according to $S_{j}$ 's calculations. The higher the value of $S_{j}$, the more important is the risks group.

Hwang and Yoon (1981) introduced the TOPSIS method. The method gain popularity for due to its ease of use and understandable application. Compared to other methods available, TOPSIS may be more stable in the data variation case (Kraujaliene 2019). This method's main principle is that the optimal dote should have the farthest point in the distance from the negative ideal solution point and the shortest line from the positive ideal solution (Dandage et al. 2018). The application of the TOPSIS method involves four steps: (1) normalization procedure; (2) calculation of the best and the worst alternatives; (3) calculation of the distance to the ideal solution and the worst solution; (4) prioritization of risk groups according to the calculated values. TOPSIS can be applied to minimising indicators and maximising ones, i.e., there is no need to convert indicators. The method, TOPSIS, utilizes vector normalization (Podviezko and Podvezko 2014), as described in the following equation.

$$
\widetilde{r}_{i j}=\frac{r_{i j}}{\sqrt{\sum_{j=1}^{n} r_{i j}^{2}}}
$$

After the normalization procedure, the best alternative $V^{+}$and the worst alternative $V^{-}$needs to be chosen. 
Then the distance $D_{j}^{+}$of every considered alternative to the ideal solution and its distance $D_{j}^{-}$to the worst solution needs to be calculated using the following equation (Podviezko and Podvezko 2014).

$$
\begin{aligned}
& D_{j}^{+}=\sqrt{\sum_{i=1}^{m}\left(\omega_{i} \widetilde{r}_{i j}-V_{i}^{+}\right)^{2}} \\
& D_{j}^{-}=\sqrt{\sum_{i=1}^{m}\left(\omega_{i} \widetilde{r}_{i j}-V_{i}^{-}\right)^{2}}
\end{aligned}
$$

The main cumulative criterion $C_{j}$ 's is calculated (Podviezko and Podvezko 2014) by the following equation.

$$
C_{j}^{*}=\frac{D_{j}^{-}}{D_{j}^{*}+D_{j}^{-}} ;(j=1,2, \ldots, n),\left(0 \leq C_{j}^{*} \leq 1\right)
$$

Risk groups are arranged according to $C_{j}$ 's calculations. The closer the value of $C_{j}$ is to 1 , the more important the risk group is.

If the two multicriteria methods results differ in assessing risk groups or possesses the same value, a third method can be used for a more accurate risk group ranking. In the scientific literature, the use of geometric mean weights of (normalised) indicators were considered superior to simpler and more common "weighted arithmetic mean" (Tom and Rogge 2016). The geometric mean is calculated according to Chakraborty and Zavadskas in the following equation (Chakraborty and Zavadskas 2014).

$$
\Pi_{j}=\sqrt[m]{\prod_{i=1}^{m} \widetilde{r}_{i j}}
$$

See $\widetilde{r}_{i j}$ calculation in Formulas (1) and (2). Coincidence of group values shall be verified before determining the significance of import risks groups by using different multicriteria methods. In the case of discrepancies, the results of different methods are summarised and the final assessment of the significance of risk groups is carried out (Palevičius et al. 2016). The framework of import risk assessment CIRA is based on the results of risk group assessments according to their importance.

\section{Research Results}

As mentioned in the literature review, the framework of eight risk groups was developed: supply risks, demand risks, production risks, management and operational risks,

\begin{tabular}{|c|c|c|c|c|c|c|c|c|c|}
\hline Risk Group & Weights & $\mathrm{E}_{1} *$ & $\mathrm{E}_{2} *$ & $\mathrm{E}_{3} *$ & $\mathrm{E}_{4} *$ & $\mathrm{E}_{5} *$ & $\mathrm{E}_{6} *$ & $\mathrm{E}_{7} *$ & $S_{j}$ \\
\hline Supply risks & 0.111 & 3.50 & 2.00 & 1.62 & 2.33 & 1.50 & 3.94 & 1.40 & 0.26 \\
\hline Demand risks & 0.101 & 1.75 & 2.00 & 3.23 & 2.33 & 1.50 & 2.63 & 1.40 & 0.21 \\
\hline Production risks & 0.160 & 5.25 & 3.00 & 3.23 & 2.33 & 3.00 & 3.94 & 2.80 & 0.54 \\
\hline Management and operational risks & 0.118 & 1.75 & 3.00 & 3.23 & 2.33 & 3.00 & 2.63 & 1.40 & 0.29 \\
\hline Logistical and infrastructural risks & 0.146 & 3.50 & 3.00 & 3.23 & 4.67 & 3.00 & 1.31 & 2.80 & 0.45 \\
\hline Political risks & 0.117 & 1.75 & 3.00 & 1.62 & 2.33 & 3.00 & 1.31 & 4.20 & 0.29 \\
\hline Policy and regulatory risks & 0.110 & 1.75 & 2.00 & 1.62 & 2.33 & 3.00 & 2.63 & 2.80 & 0.25 \\
\hline Financial risks & 0.137 & 1.75 & 3.00 & 3.23 & 2.33 & 3.00 & 2.63 & 4.20 & 0.39 \\
\hline
\end{tabular}
logistical and infrastructural risks, political risks, policy and regulatory risks and financial risks. The results using the SAW method are presented in Table 3.

Table 3. Assessment of import risk groups using the SAW method.

${ }^{*}$ Normalised values.

According to the SAW method, the significance of the risk groups is as follows: production risks (the most crucial risk), logistical and infrastructural risks, financial risks, 
management and operational risks, political risks, supply risks, policy and regulatory risks and demand risks.

The results using the TOPSIS method are presented in Table 4.

Table 4. Assessment of import risk groups using the TOPSIS method.

\begin{tabular}{ccccccccccc}
\hline Risk Group & $\mathbf{E}_{\mathbf{1}} *$ & $\mathbf{E}_{\mathbf{2}}{ }^{*}$ & $\mathbf{E}_{\mathbf{3}} *$ & $\mathbf{E}_{\mathbf{4}} *$ & $\mathbf{E}_{\mathbf{5}} *$ & $\mathbf{E}_{\mathbf{6}} *$ & $\mathbf{E}_{\mathbf{7}} *$ & $\mathbf{D}^{+}$ & $\mathbf{D}^{-}$ & $C_{j}$ \\
\hline Supply risks & 0.43 & 0.26 & 0.21 & 0.30 & 0.20 & 0.50 & 0.17 & 0.60 & 0.40 & 0.40 \\
Demand risks & 0.21 & 0.26 & 0.42 & 0.30 & 0.20 & 0.33 & 0.17 & 0.69 & 0.27 & 0.28 \\
Production risks & 0.64 & 0.40 & 0.42 & 0.30 & 0.39 & 0.50 & 0.35 & 0.35 & 0.65 & 0.65 \\
Management and operational r. & 0.21 & 0.40 & 0.42 & 0.30 & 0.39 & 0.33 & 0.17 & 0.65 & 0.36 & 0.35 \\
Logistical and infrastructural r. & 0.43 & 0.40 & 0.42 & 0.60 & 0.39 & 0.17 & 0.35 & 0.43 & 0.52 & 0.54 \\
Political risks & 0.21 & 0.40 & 0.21 & 0.30 & 0.39 & 0.17 & 0.52 & 0.65 & 0.42 & 0.39 \\
Policy and regulatory risks & 0.21 & 0.26 & 0.21 & 0.30 & 0.39 & 0.33 & 0.35 & 0.63 & 0.31 & 0.33 \\
Financial risks & 0.21 & 0.40 & 0.42 & 0.30 & 0.39 & 0.33 & 0.52 & 0.55 & 0.50 & 0.48 \\
\hline
\end{tabular}

${ }^{*}$ Normalised values.

The best alternative $V^{+}$and the worst alternative $V^{-}$according to the TOPSIS method are presented in Table 5.

Table 5. The best alternative $V^{+}$and the worst alternative $V^{-}$results according the TOPSIS.

\begin{tabular}{cccccccc}
\hline Alternatives & $\mathbf{E}_{\mathbf{1}}$ & $\mathbf{E}_{\mathbf{2}}$ & $\mathbf{E}_{\mathbf{3}}$ & $\mathbf{E}_{\mathbf{4}}$ & $\mathbf{E}_{\mathbf{5}}$ & $\mathbf{E}_{\mathbf{6}}$ & $\mathbf{E}_{\mathbf{7}}$ \\
\hline Best alternative $V^{+}$ & 0.640 & 0.397 & 0.417 & 0.603 & 0.392 & 0.500 & 0.522 \\
Worst alternative $V^{-}$ & 0.213 & 0.265 & 0.209 & 0.302 & 0.196 & 0.167 & 0.174 \\
\hline
\end{tabular}

According to TOPSIS expert evaluation method, the significance of the risk according to their importance was as follows: production risks (the most crucial risk), logistical and infrastructural risks, financial risks, supply risks, political risks, management and operational risks, policy and regulatory risks, demand risks.

The results of risk group evaluation according to their importance using the SAW and TOPSIS methods differs. In order to determine the straightforward approach of the significance of the risk groups another technique - the Geometric mean (GM) method-is used. The results are presented in Table 6.

Table 6. Assessment of import risk groups using the Geometric mean.

\begin{tabular}{ccccccccc}
\hline Risk Group & $\mathbf{E}_{\mathbf{1}}{ }^{*}$ & $\mathbf{E}_{\mathbf{2}}{ }^{*}$ & $\mathbf{E}_{\mathbf{3}}{ }^{*}$ & $\mathbf{E}_{\mathbf{4}} *$ & $\mathbf{E}_{5} *$ & $\mathbf{E}_{\mathbf{6}} *$ & $\mathbf{E}_{\mathbf{7}} *$ & $\mathbf{G M}^{*}$ \\
\hline Supply risks & 0.667 & 0.667 & 0.500 & 0.500 & 0.500 & 1.000 & 0.333 & 0.607 \\
Demand risks & 0.333 & 0.667 & 1.000 & 0.500 & 0.500 & 0.667 & 0.333 & 0.577 \\
Production risks & 1.000 & 1.000 & 1.000 & 0.500 & 1.000 & 1.000 & 0.667 & 0.872 \\
Management and operational risks & 0.333 & 1.000 & 1.000 & 0.500 & 1.000 & 0.667 & 0.333 & 0.662 \\
Logistical and infrastructural risks & 0.667 & 1.000 & 1.000 & 1.000 & 1.000 & 0.333 & 0.667 & 0.788 \\
Political risks & 0.333 & 1.000 & 0.500 & 0.500 & 1.000 & 0.333 & 1.000 & 0.639 \\
Policy and regulatory risks & 0.333 & 0.667 & 0.500 & 0.500 & 1.000 & 0.667 & 0.667 & 0.630 \\
Financial risks & 0.333 & 1.000 & 1.000 & 0.500 & 1.000 & 0.667 & 1.000 & 0.760 \\
\hline
\end{tabular}

* Normalised values.

The import risks assessment according to their importance by the Geometric mean are ordered in the following manner: production risks (most crucial risk group), logistical and infrastructural risks, financial risks, management and operational risks, political risks, policy and regulatory risks, supply risks and demand risks. The place order of risk groups also differs from previous estimates. The summarised results of risk group assessment are presented in Table 7. 
Table 7. Summarised results of import risk groups.

\begin{tabular}{ccccc}
\hline Groups of Risk & SAW Range & TOPSIS Range & GM Range & Total Range \\
\hline Supply risks & 6 & 4 & 7 & 8.7 \\
Demand risks & 8 & 8 & 1 & 8.0 \\
Production risks & 1 & 1 & 4 & 1.0 \\
Management and operational risks & 4 & 6 & 2 & 4.7 \\
Logistical and infrastructural risks & 2 & 5 & 5 & 5.0 \\
Political risks & 5 & 7 & 6 & 6.7 \\
Policy and regulatory risks & 7 & 3 & 3 & 3.0 \\
Financial risks & 3 & 5 & \\
\hline
\end{tabular}

The importance of import risks summarized by all used methods is as follows: production risks (most crucial risk group), logistical and infrastructural risks, financial risks, management and operational risks, political risks, supply risks, policy and regulatory risks and demand risks. According to this assessment, the final framework-CIRA-is developed. This new import risk assessment framework contributes to the systematic approach of a country's international trade risk management.

\section{Discussion and Conclusions}

Literature analyses shows that the relevance of the risk is increasing and it covers several aspects. Import risk management is important not only for companies but also for each country. Assessing the risks posed by imports is vital for the well-being of the country's population (improving the quality of life) and for its security (in the context of food security, economic and political welfare). It is significant for the country to not only monitor export risks but also to manage import risks. Normally, authors analyse the key risk factors. Our research has shown that the risk factors examined by most authors (Huang et al. 2017; Hyuha et al. 2017) belong to the group of production risks (e.g., country security, unequal distribution of resources and labor market factors), which the country needs to manage the most.

In addition, without managing import risks and especially risks included in production risk group, the country's security is threatened. Leaving it to self-process (under self-interested businesses) may result in insecurity relative to population interests. In order to manage this group of risks, there is a need for political interventions that contribute to OECD (2020) analysis. After analysing the import risk groups presented by various authors, the new framework for CIRA was developed. Our research is primarily based on supply chain risk management, which is also the focus of other researchers (e.g., Nyamah et al. 2017; Spink et al. 2019; Zhao et al. 2020). However, considering the specificities of agricultural products, the role of food quality risk and other import risks observed by other scientists (Welburn et al. 2016; Herrera-Herrera et al. 2019; Attrey 2017; Ruhm 2016; Smith et al. 2017) and that are incorporated into risk groups has been expanded to form a common framework for CIRA. It allows the analysis of all import risk groups of a country by using one framework.

Using multicriteria decision support methods, risk groups were assessed according to the importance of countrywide governance. As all risk groups are significant in the supply chain, it is vital to determine which groups of risks are relevant for governmental management. Since all multicriteria decision support methods have their disadvantages, the use of the three methods ensures an optimal result. In addition, the rating of risk groups allows politicians to focus more clearly, for which risk groups more attention should be given and which should be managed first. It allows using CIRA widely in practice, including the increase in export or reduce of imports and the balance of a country's trade to incorporate import risk management.

The results of our research showed that managing the production risks group is most crucial. This can be explained by the fact that most of the factors involved in this group are related to the primary production of agricultural products and are mainly directed to 
primary production where the role of the country's government could be most significant. Our results show that the import of primary agro products is seen as the most significant risk. However, the situation may differ from one product group to another. For example, the distribution of risk groups in the supply chains of processed food products may vary according to importance.

Further studies are needed to assess the import risks of the different product categories. Nevertheless, managing imports of primary production is the most important for the country. According to our research, the distributions of other risk groups are as follows: logistical and infrastructural risks, financial risks, management and operational risks, political risks, supply risks, policy and regulatory risks and demand risks. It demonstrates the importance of supporting sectors management in the interest of ensuring the effective functioning of whole supply chains. According to importance, groups of risks can differ in importance due to the countries from which imports are produced. The need for further research is required. It could bring a broader perspective of the importance of the import risks factors and not only risk groups and their effect on business when planning, managing or mitigating an import from different counties or various product groups. Researchers could also analyse import risks in other supply networks (e.g., different retail chains).

Groups of risks can differ according to the countries from which imports are made. The need for further research is required. It could bring a broader perspective of the risk factors and their effect that businesses should consider when planning, managing or mitigating an import from different counties or various product groups.

The research has some limitations. CIRA framework covers risks related at the country level. Future research might cover factors that assesses, with particular attention, and identifies import risk factors for different food product groups. Those factors could also be ranked and compared between different food products groups (e.g., dairy products, grains, beverages, processed food, ready to eat food, etc.). Further research could also bring a wider perspective of the risk factors for separated country groups or different countries. Furthermore, combined (quantitative and qualitative) risk evaluation methods could be used.

Author Contributions: Conceptualization, methodology, investigation, writing-original draft preparation L.B.; supervision and writing, review and editing D.J. All authors have read and agreed to the published version of the manuscript.

Funding: This research received no external funding.

Institutional Review Board Statement: Informed consent was obtained from all subjects involved in the study.

Conflicts of Interest: The authors declare no conflict of interest.

\section{References}

Aday, Serpil, and Mehmet Seckin Aday. 2020. Impact of COVID-19 on the food supply chain. Food Quality and Safety 4: 167-80. [CrossRef]

Adda, Jérôme, and Yarine Fawaz. 2020. The health toll of import competition. The Economic Journal 130: 1501-40. [CrossRef]

Attrey, Dharam Paul. 2017. Food safety in international food trade-Imports and exports. In Food Safety in the 21st Century. Cambridge: Academic Press, pp. 455-68. [CrossRef]

Bach, Vanessa, Markus Berger, Martin Henßler, Martin Kirchner, Stefan Leiser, Lisa Mohr, and Wolfgang Volkhausen. 2016. Integrated method to assess resource efficiency-ESSENZ. Journal of Cleaner Production 137: 118-30. [CrossRef]

Bach, Vanessa, Natalia Finogenova, Markus Berger, Lisa Winter, and Matthias Finkbeiner. 2017. Enhancing the assessment of critical resource use at the country level with the SCARCE method-case study of Germany. Resources Policy 53: 283-99. [CrossRef]

Bachev, Hrabrin. 2017. Supply Chain Risk Management-Agri-Food Implications. Noble International Journal of Business and Management Research 1: 10-30.

Baryannis, George, Sahar Validi, Samir Dani, and Grigoris Antoniou. 2019. Supply chain risk management and artificial intelligence: State of the art and future research directions. International Journal of Production Research 57: 2179-202. [CrossRef]

Behzadi, Golnar, Michael Justin O'Sullivan, Tava Lennon Olsen, and Abraham Zhang. 2018. Agribusiness supply chain risk management: A review of quantitative decision models. Omega 79: 21-42. [CrossRef] 
Caccavale, Oscar Maria, and Valerio Giuffrida. 2020. The Proteus composite index: Towards a better metric for global food security. World Development 126: 104709. [CrossRef]

Chakraborty, Shankar, and Edmundas Kazimieras Zavadskas. 2014. Applications of WASPAS method in manufacturing decision making. Informatica 25: 1-20. [CrossRef]

Colantone, Italo, and Piero Stanig. 2018. The trade origins of economic nationalism: Import competition and voting behavior in Western Europe. American Journal of Political Science 62: 936-53. [CrossRef]

Dandage, Rahul, Shankar S. Mantha, and Santosh B. Rane. 2018. Ranking the risk categories in international projects using the TOPSIS method. International Journal of Managing Projects in Business 11: 317-31. [CrossRef]

Drozdz, Jolanta. 2018. Specialisation in agricultural and food exports of Lithuania. Business and Management 10: 200-7.

EC (European Commission). 2015. Trade and Investment Strategy for the European Union. Trade for All: Towards a More Responsible Trade and Investment Policy. Available online: https: / /ec.europa.eu/trade/policy/in-focus/new-trade-strategy/ (accessed on 10 March 2021).

Feng, Ling, Zhiyuan Li, and Deborah L. Swenson. 2016. The connection between imported intermediate inputs and exports: Evidence from Chinese firms. Journal of International Economics 101: 86-101. [CrossRef]

Gemechu, D. Eskinder, Christoph Helbig, Guido Sonnemann, Andrea Thorenz, and Axel Tuma. 2016. Import-based indicator for the geopolitical supply risk of raw materials in life cycle sustainability assessments. Journal of Industrial Ecology 20: 154-65. [CrossRef]

Gervais, Antoine. 2018. Uncertainty, risk aversion and international trade. Journal of International Economics 115: 145-58. [CrossRef]

Ginevičius, Romualdas, and Valentinas Podvezko. 2008. The problem of compatibility of various multiplecriteria evaluation methods. Business: Theory and Practice 9: 73-80.

Hardaker, J. Brian, Gudbrand Lien, Jock R. Anderson, and Ruud B. M. Huirne. 2015. Coping with Risk in Agriculture: Applied Decision Analysis. Wallingford: CABI, ISBN 9781780645742.

Herrera-Herrera, Claudia, Fabio Fuentes-Gandara, Alejandra Zambrano-Arévalo, Faisal Bernal Higuita, Jose Pinedo Hernández, and Jose Marrugo-Negrete. 2019. Health risks associated with heavy metals in imported fish in a coastal city in Colombia. Biological Trace element Research 190: 526-34. [CrossRef]

Ho, William, Tian Zheng, Hakan Yildiz, and Srinivas Talluri. 2015. Supply chain risk management: A literature review. International Journal of Production Research 53: 5031-69. [CrossRef]

Hoekman, Bernard. 2019. Urgent and important: Improving WTO performance by revisiting working practices. Journal of World Trade 53: 373-94.

Huang, Ji-Kun, Wei Wei, Qi Cui, and Xie Wei. 2017. The prospects for China's food security and imports: Will China starve the world via imports? Journal of Integrative Agriculture 16: 2933-44. [CrossRef]

Hyuha, T., Ekere William, and Bantebya Kyomuhendo Grace. 2017. Determinants of import demand of rice in Uganda. International Journal of Applied and Pure Science and Agriculture 3: 75-81.

Hwang, Ching-Lai, and Kwangsun Yoon. 1981. Multiple Attribute Decision Making Methods and Applications. Berlin: Springer-Verlag. [CrossRef]

Ivanov, Dmitry, lexandre, olgui, oris, and okolov. 2019. The impact of digital technology and Industry 4.0 on the ripple effect and supply chain risk analytics. International Journal of Production Research 57: 829-46. [CrossRef]

Jablonski, Becca B. R., Joy Casnovsky, Jill K. Clark, Rebecca Cleary, Beth Feingold, Darcy Freedman, Steven Gray, Steven Gray, Xiaobo Romeiko, Laura Schmitt, and et al. 2021. Emergency food provision for children and families during the COVID-19 pandemic: Examples from five US cities. Applied Economic Perspectives and Policy 43: 169-84. [CrossRef] [PubMed]

Jámbor, Attila, Péter Gál, and Áron Török. 2020. Determinants of regional trade agreements: Global evidence based on gravity models. Journal of International Studies 13: 44-57. [CrossRef] [PubMed]

Jindřichovská, Irena. 2020. On the relevance of gravity model in the new institutional environment. Slovak Journal of Public Policy and Public Administration 7. Available online: https://sjpppa.fsvucm.sk/index.php/journal/article/view/98 (accessed on 20 June 2021).

Keynes, John Maynard, and Paul A. Volcker. 1920. The Economic Consequences of the Peace. London: Macmillan, vol. 178.

Khanal, Uttam, Clevo Wilson, Viet-Ngu Hoang, and Boon Lee. 2018. Farmers' adaptation to climate change, its determinants and impacts on rice yield in Nepal. Ecological Economics 144: 139-47. [CrossRef]

Kraujalienè, Lidija. 2019. Comparative analysis of multicriteria decision-making methods evaluating the efficiency of technology transfer. Business, Management and Education 17: 72-93. [CrossRef]

Kulikov, Ivan Michailovic, and Ivan Alekseevic Minakov. 2018. Priority directions of agricultural development under import substitution and the formation of export-oriented economy. Economy, Labor, Management in Agriculture 9: 30-36. [CrossRef]

Laborde, David, Will Martin, Johan Swinnen, and Rob Vos. 2020. COVID-19 risks to global food security. Science 369: 500-2. [CrossRef]

Lang, Matthew, T. Clay McManus, and Georg Schaur. 2019. The effects of import competition on health in the local economy. Health Economics 28: 44-56. [CrossRef]

Libby, Robert, and Roger K. Blashfield. 1978. Performance of a composite as a function of the number of judges. Organizational Behavior and Human Performance 21: 121-29. [CrossRef]

MacCrimmon, Kenneth R. 1968. Decision Making Among Multiple-Attribute Alternatives: A Survey and Consolidated Approach. Rand Corp Santa Monica Ca. RAND Memorandum, RM-4823-ARPA. The RAND Corporation, Santa Monica, Calif. Available online: https:/ / apps.dtic.mil/sti/citations / AD0681005 (accessed on 4 January 2021). 
Mehrolia, Sangeeta, Subburaj Alagarsamy, and Vijay Mallikraj Solaikutty. 2020. Customers Response to Online Food Delivery Services during COVID-19 Outbreak Using Binary Logistic Regression. International Journal of Consumer Studies 45: 396-408. [CrossRef] [PubMed]

Moreno, Blanca, and María Teresa García-Álvarez. 2018. Measuring the progress towards a resource-efficient European Union under the Europe 2020 strategy. Journal of Cleaner Production 170: 991-1005. [CrossRef]

NAO. 2013. Food Safety and Authenticity in the Processed Meat Supply Chain. The Food Standards Agency, Department for Environment, Food \& Rural Affairs, Department of Health. Available online: https:/ /www.nao.org.uk/wp-content/uploads/20 14/10/10255-001-Food-safety-and-authenticity.pdf (accessed on 10 January 2021).

Novickyte, Lina. 2019. Risk in agriculture: An overview of the theoretical insights and recent development trends during last decade-A review. Agricultural Economics 65: 435-44. [CrossRef]

Nyamah, Edmond Yeboah, Yuansheng Jiang, Yi Feng, and Eevelyn Enchill. 2017. Agri-food supply chain performance: An empirical impact of risk. Management Decision 55: 872-91. [CrossRef]

OECD. 2020. Making Better Policies for Food Systems. OECD Trade and Agriculture Directorate, Publication. Available online: https:/ / www.oecd-ilibrary.org/sites/ddfba4de-en/1/2/1/index.html?itemId=/content/publication/ddfba4de-en\&csp= 2d2e29d3de4686546a54d761a8a8a426\&itemIGO=oecd\&itemContentType=book (accessed on 19 January 2021).

Otero, Gerardo, Efe Can Gürcan, Gabriela Pechlaner, and Giselle Liberman. 2018. Food security, obesity, and inequality: Measuring the risk of exposure to the neoliberal diet. Journal of Agrarian Change 18: 536-54. [CrossRef]

Palevičius, Vytautas, Vytautas Grigonis, Askoldas Podviezko, and Greta Barauskaite. 2016. Developmental analysis of park-and-ride facilities in Vilnius. Promet-Traffic \& Transportation 28: 165-78. [CrossRef]

Pietrzyck, Katja, Nora Berke, Vanessa Wendel, Julia Steinhoff-Wagner, Sebastian Jarzębowski, and Brigitte Petersen. 2021. Understanding the Importance of International Quality Standards Regarding Global Trade in Food and Agricultural Products: Analysis of the German Media. Agriculture 11: 328. [CrossRef]

Podviezko, Askoldas, and Valentinas Podvezko. 2014. Absolute and relative evaluation of socio-economic objects based on multiple criteria decision-making methods. Engineering Economics 25: 522-29. [CrossRef]

Rieger, Jörg, Christian Kuhlgatz, and Sven Anders. 2016. Food scandals, media attention and habit persistence among desensitised meat consumers. Food Policy 64: 82-92. [CrossRef]

Ruhm, Christopher J. 2016. Health effects of economic crises. Health Economics 25: 6-24. [CrossRef]

Sharma, Rohit, Anjali Shishodia, Sachin Kamble, Angappa Gunasekaran, and Amine Belhadi. 2020. Agriculture supply chain risks and COVID-19: Mitigation strategies and implications for the practitioners. International Journal of Logistics Research and Applications, 1-27. [CrossRef]

Shmatko, Nataliia, Andrii Bondarenko, Yevheniia Kaliuha, Liliia Kozachenko, Liubov Shevtsiv, and Denys Sedikov. 2020. Logistic convergence as a mechanism of modification the system of management accounting of import operations at enterprises. International Journal of Management (IJM) 11: 551-64.

Skuland, Silje Elisabeth. 2020. European Food Safety: Mapping Critical Food Practices and Cultural Differences in France, Norway, Portugal, Romania and the UK. Report 6-2020. Available online: https://hdl.handle.net/20.500.12199/3112 (accessed on 21 February 2021).

Smith, Karl, Carlos Zambrana-Torrelio, Anne White, Marianne Asmussen, Catherine Machalaba, Stephen Kennedy, Katherine Lopez, Thomas M. Wolf, Peter Daszak, and et al. 2017. Summarizing US wildlife trade with an eye toward assessing the risk of infectious disease introduction. EcoHealth 14: 29-39. [CrossRef] [PubMed]

Spink, John, P.Vincent Hegarty, Neal D. Fortin, Christopher T. Elliott, and Douglas C. Moyer. 2019. The application of public policy theory to the emerging food fraud risk: Next steps. Trends in Food Science E Technology 85: 116-28. [CrossRef]

World Economic Forum. 2019. The Global Risks Report 2019. In The World Economic Forum in partnership with Marsh E McLennan Companies and Zurich Insurance Group. Geneve: World Economic Forum. Available online: https: / /www.weforum.org/reports/ the-global-risks-report-2019 (accessed on 17 March 2021).

Van den Berg, Henk, Gamini Manuweera, and Flemming Konradsen. 2017. Global trends in the production and use of DDT for control of malaria and other vector-borne diseases. Malaria Journal 16: 1-8. [CrossRef]

Van den Berg, Marcel, Charles van Marrewijk, and Saara Tamminen. 2018. Trade, productivity and profitability: On profit levels and profit margins. The World Economy 41: 2149-74. Available online: https:/ /doi.org/10.1111/twec.12630 (accessed on 21 June 2021).

Van den Berg, Marcel, and Charles Van Marrewijk. 2017. Imports and productivity: The impact of geography and factor intensity. The Journal of International Trade E Economic Development 26: 425-50. [CrossRef]

Tom, Van Puyenbroeck, and Nicky Rogge. 2016. Geometric Mean Quantity Index. Numbers with BenePt-of-the-Doubt Weights. European Journal of Operational Research 256: 1004-14. [CrossRef]

Wagner, Joachim. 2012. International trade and firm performance: A survey of empirical studies since 2006. Review of World Economics 148: 235-67. [CrossRef]

Wagner, Joachim. 2013. Exports, imports and firm survival: First evidence for manufacturing enterprises in Germany. Review of World Economics 149: 113-30. [CrossRef]

Welburn, Jonathan, Vicki Bier, and Steven Hoerning. 2016. Import security: Assessing the risks of imported food. Risk Analysis 36: 2047-64. [CrossRef] 
Wymenga, Paul, Nora Plaisier, and Jurgen Vermeulen. 2013. Study on Support Services for SMEs in International Business. Rotterdam: ECSIP Consortium.

Yu, Wusheng, Tianxiang Li, and Jing Zhu. 2019. What Determines China's Grain Imports and Self-sufficiency? The Role of Rising Domestic Costs and Varying World Market Prices. China \& World Economy 27: 1-24. [CrossRef]

Zhao, Guoqing, Shaofeng Liu, Carmen Lopez, Huilan Chen, Haiyan Lu, Sachin Kumar Mangla, and Sebastian Elgueta. 2020. Risk analysis of the agri-food supply chain: A multi-method approach. International Journal of Production Research 58: 4851-76. [CrossRef]

Zhu, Wenbin, Shaofeng Jia, Naresh Devineni, Aifeng Lv, and Upmanu Lall. 2019. Evaluating China's water security for food production: The role of rainfall and irrigation. Geophysical Research Letters 46: 11155-66. [CrossRef]

Zobov, Alexander M., Ekaterina A. Degtereva, Veronica Y. Chernova, and Vasily S. Starostin. 2017. Comparative analysis of the best practices in the economic policy of import substitution. European Research Studies 20: 507-20. 